\title{
JUDGING CONSTITUTIONAL CONVENTIONS ${ }^{\dagger}$
}

\author{
Farrah Ahmed, Melbourne Law School, University of Melbourne \\ Richard Albert, The University of Texas School of Law \\ Adam Perry, University of Oxford, Faculty of Law
}

\begin{abstract}
The study of constitutional conventions is anchored in three assumptions that have so far remained largely unchallenged: that there is a shared "Commonwealth approach" to constitutional conventions; that Commonwealth courts will recognize and employ conventions but never enforce them; and that conventions are always distinguishable from rules of law. We overturn each of these assumptions in this Article. We argue that there is no such shared "Commonwealth approach" to the treatment of constitutional conventions, that Commonwealth courts do, in fact, enforce conventions, and that constitutional conventions have crystallized into law in a major Commonwealth jurisdiction. These insights disrupt much of what is foundational in the study of constitutional conventions.
\end{abstract}

\footnotetext{
${ }^{\dagger}$ For comments on an earlier draft, we are grateful to Nick Barber, Tom Daly, Rosalind Dixon, Jeffrey Goldsworthy, Aileen Kavanagh, Jeff King, Janet McLean, Peter Oliver, Glenn Patmore, Adrienne Stone, Adam Tucker, Lulu Weis, Alison Young and other participants at the Workshop on Constitutional Boundaries held in August 2017 with the generous support of the Oxford-MLS Research Partnership. We are grateful to Melbourne Law School for hosting Richard Albert and Adam Perry as Visiting Scholars to work on-site with Farrah Ahmed toward completion of this Article. We also thank the team at the International Journal of Constitutional Law and their anonymous reviewers for constructive comments and helpful suggestions on an earlier draft.
} 


\section{INTRODUCTION}

The late O. Hood Phillips isolated the essential characteristic of constitutional conventions in a simple phrase: "These are not a

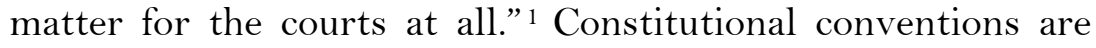
commonly described as obligatory but non-justiciable rules that are central to the functioning of government. ${ }^{2}$ The scholarly literature takes for granted that there exists a "Commonwealth approach" to how courts understand and in turn treat conventions. ${ }^{3}$ Adrian Vermeule, for example, observes that the Commonwealth approach-which "holds that while courts may and should recognise conventions, they may not and should not enforce them" - - has "achieved consensus in the United Kingdom and the Commonwealth." ${ }_{5}$ There is a similar consensus that conventions are always distinguishable from rules of law. ${ }^{6}$

${ }^{1}$ O. Hood. Phillips, Constitutional Conventions: A Conventional Reply, 8 J. SoC'Y Pub. Teachers L. 60, 64 (1964).

2 To draw from a recent and useful restatement, a constitutional convention is "a sense of obligation which either is, or ought to be felt by the persons subject to the supposed convention, as demonstrated by precedent or agreement; the constitutional nature of the obligation; its importance in the constitutional system; and a reason to support it." Greg Taylor, Convention by Consensus: Constitutional Conventions in Germany, 12 INT'L J. CONST. L. 303, 323 (2014).

${ }^{3}$ See, e.g., A.V. Dicey, Introduction to the Study of the LaW of The Constitution cxli (Liberty Fund 8th ed., 1915); EDward A. FreEman, ThE GRowTH of THE ENGLISH CONSTITUTION FROM THE EARLIEST TIMES 116-17 (1873); Ivor Jennings, The LaW and THE Constitution 103 (1959); Geoffrey Marshall, Constitutional Conventions: The Rules And Forms of Political Accountability 12-18 (1987); Eugene A. Forsey, The Courts and the Conventions of the Constitution, 33 U.N.B. L.J. 11, 12 (1984).

${ }^{4}$ Adrian Vermeule, Conventions in Court, 38 Dublin U. L.J. 283, 284 (2015).

${ }^{5} I d$.

${ }^{6}$ See, e.g., Colin Munro, Laws and Conventions Distinguished, 91 L. Q. REV. 218 , 228 (1975) ("The validity of conventions cannot be the subject of proceedings in a court of law. Reparation for breach of such rules will not be effected by any legal sanction. ... In fact, the idea of a court enforcing a mere convention is so strange that the question hardly arises."); Léonid Sirota, Towards a Jurisprudence of Constitutional Conventions, 11 OxFORD U. COMMONWEALTH L.J. 29, 51 (2011) ("There exists, in the constitutional theory of Commonwealth jurisdictions, a long-standing distinction between 
In this Article we show that this dominant view is mistaken. We demonstrate, first, that Commonwealth courts go beyond simply recognizing the existence of conventions to employ them in legal reasoning towards the resolution of a dispute. Second, and more significantly, we show that courts do what the dominant view says they cannot: they enforce conventions to resolve legal disputes before them. Finally, we show that we have found of one of the "holy grails" of Commonwealth constitutional scholarship ${ }^{7}$ : a convention that has crystallized into law-something that has until now eluded public law scholars.

We focus on high courts in Canada, India, and the United Kingdom - three Commonwealth jurisdictions with historically shared legal norms around conventions-because their constitutional case law illustrates the range of options available to courts when engaging with conventions. To our knowledge, the recent cases at the core of our analysis have yet to be examined with the comparative and theoretical perspectives we take in this Article. We focus specifically on Miller v. Secretary of State for Exiting the European Union (2017) at the UK Supreme Court, ${ }^{8}$ the National Judicial Appointments Commission ${ }^{9}$ case (2015) and earlier related controversies at the Indian Supreme Court, as well as the Canadian Supreme Court's Patriation Reference which is thought to represent-incorrectly, we showthe Commonwealth approach to conventions in courts. ${ }^{10}$

Three of our conclusions are especially noteworthy. First, as we have highlighted above, scholarly claims and their derivative implications about a consistent "Commonwealth approach" to conventions are mistaken. Second, and more importantly for the

constitutional law 'proper' and constitutional conventions-rules of political morality having a shadowy existence beside, above, and underneath the law.”).

${ }^{7}$ N.W. Barber, Law and Constitutional Conventions, 125 L. Q. REV. 294 (2009) 302..

8 R. (Miller) v. Secretary of State for Exiting the European Union, [2017] U.K.S.C. 5 ("Miller").

9 Supreme Court Advocates-on-Record Association v. Union of India, [2015] SCC OnLine SC 964 ("NJAC").

${ }^{10}$ Reference re: Resolution to Amend the Constitution, [1981] 1 S.C.R. 753 ("Patriation Reference"). 
study of constitutional conventions, the unchallenged and practically axiomatic truth that Commonwealth courts do not enforce constitutional conventions is incorrect. Third, and as a result, there is reason to think that constitutional conventions in at least one Commonwealth jurisdiction have crystallized into law. Future scholarship on constitutional conventions will have to confront our evidence.

We begin, in Part II, with an inquiry into the ways courts conceivably could engage with conventions. We distinguish specifically among three modes of engagement-recognition, employment and enforcement - as well as the variations within each in order to set the terms for Part III, where we review how Commonwealth courts actually do engage with conventions. We show that high court judgments in Canada, India and the United Kingdom together demonstrate all three of these modes of judicial engagement, suggesting that Commonwealth courts engage with conventions in ways that have until now been undertheorized and underexplored in the scholarly literature. Building on our discussion in Parts II and III, we suggest in Part IV that India may provide the first example of the crystallization of a constitutional convention into law.

\section{MODES OF JUDICIAL ENGAGEMENT}

Judges engage with many types of rules that we can classify under two headings: legal rules, including domestic laws, foreign laws, and rules of international law; and non-legal rules, for instance lex mercatoria, rules of professional, religious, and sporting bodies, and moral rules as well. Constitutional conventions are another example of non-legal rules, and in principle judges can engage with conventions in the same ways they engage with virtually any other legal and non-legal rules. Judges might in theory praise or criticize, follow or flout, promote, adopt, endorse, or undermine a rule in either of these two categories. In this Part, we outline the three most important modes of judicial engagement with constitutional conventions. 


\section{A. Recognition}

Perhaps the simplest form of judicial engagement with conventions is the recognition of a convention's existence or its scope. Recognition is a fact-finding activity; the judge engages with the convention on a factual basis. If the existence or scope of the convention is uncontroversial, recognition might take the form of judicial notice. If on the other hand the convention is controversial, then there is a disputed question of fact. The judge will consider the relevant evidence and reach a determination about whether there is a convention and what it requires. How can the judge reliably identify whether a convention exists? In Canada, India, and the United Kingdom, judges have all turned to the same three-part test, first proposed by Sir Ivor Jennings:

We have to ask ourselves three questions: first, what are the precedents; secondly, did the actors in the precedents believe that they were bound by a rule; and thirdly, is there a reason for the rule? ${ }^{11}$

According to Jennings' test, a convention exists where there are precedents that amount to more than "mere practice," where the relevant actors believe that they must respect and reinforce those precedents, and where there exists a principled reason that sustains the conventional practice. ${ }^{12}$

There are two reasons why a judge would need to inquire into the existence or scope of a convention. For one, it may be that the judge has been asked simply whether there is a convention or whether the convention requires some act. If yes, then once the fact-finding process is over, the purpose of engaging with the convention is fulfilled. We will return to this possibility below when we discuss the judicial act of declaration. Alternatively, and more commonly, judges might inquire into the existence or scope of a convention because some legal issue turns on its existence or scope. The judge is interested here in a convention

\footnotetext{
${ }^{11}$ JENNINGS, supra note 3, at 136; Evans v. Information Commissioner, [2012] UKUT 313, para. 75 (AAC) (UK) ("Evans"); Supreme Court Advocates-onRecord Association v. Union of India, (1993) 4 S.C.C. 441, para. 444 (India) ("Second Judges Case"); Patriation Reference, supra note 10, at 888.

12 Jennings, supra note 3, at 134-36.
} 
as a means to an end because resolution of the factual issue bears on the resolution of the legal issue. This possibility takes us to the second way that judges might engage with conventions.

\section{B. Employment}

The fact that a convention exists, or that it requires some act, might be employed as a premise in the act of legal reasoning. Without intending to be exhaustive, three usages are particularly important. The hypothetical examples below illustrate how courts might actually resort to the employment of conventions. We provide concrete cases in the next Part.

1. Conventions as grounds for the interpretation of legal provisions. Statutes and codified constitutions are created within a factual context. That context is evidence of the intentions of the enactors or adopters of the statute or constitution. Insofar as conventions may form part of the factual context, conventions may bear on the proper interpretation of the statute or constitution. Suppose that a statute refers to the Prime Minister or Cabinet. In Britain, these institutions are creatures of convention, not law. In order to understand the statute, a British court would need to refer to the convention. Or, to take a more complex example, suppose that the legislature's intention is to replace a convention with a statutory rule possessing the same content. When interpreting the statute, a court would properly have regard to the (former) convention in order to understand what rule the legislature intended to enact.

2. Conventions as grounds for the application or development of laws. Legal rules typically have factual conditions for their application, and the existence of a convention may bear on whether such a condition is fulfilled. A statute might give a minister a discretionary power, and impose a duty to use this power "reasonably" or "in the public interest." Subsequently, the legal question arises whether a particular use of the power meets the relevant standard. A judge answering this question might be interested in whether the use of the power undermined a constitutional convention, in which case the convention would 
bear on the application of the legal standard. There is no sharp break between the repeated application of a common law rule in a new circumstance and the development of a new rule. As a result, a convention might influence not just what the common law requires in certain cases but what it requires in general.

3. Conventions as grounds not to develop the common law. We highlight one last way to employ conventions. It is of a different character from the previous two: here conventions are used to resist a legal conclusion rather than to support one. Consider a line of argument endorsed by many "political constitutionalists": political and legal mechanisms of accountability should complement each other; there are existing and well-functioning forms of political accountability, including the conventions of individual and ministerial responsibility; therefore, judges should be slow to develop alternate forms of legal accountability. If this argument is sound-and we need not express an opinion on that question-then the existence of certain conventions would be grounds not to develop the law in a way that would have the effect of holding political actors accountable. Judges might take the availability of conventional constraints as making the development of legal constraints unnecessary. ${ }^{13}$

\section{Enforcement}

There has been much debate on whether conventions are, or ought to be, enforceable by courts. ${ }^{14}$ While this debate has contributed significantly to our understanding of conventions, further progress has been hindered by imprecision when using the term "enforcement." In this Section we clarify the meaning of enforcement with a view to seeding a more constructive conversation. We stipulate that enforcement of a duty-imposing rule occurs through an act which (i) responds to a violation or a

\footnotetext{
13 See Oran Doyle, Constitutional Transitions, Abusive Constitutionalism and Conventional Constraint, 37 NAT'L J. ConST. L. 67 (2017).

${ }_{14}$ See, e.g., Barber, supra note 7; Mark Elliott, Parliamentary Sovereignty and the New Constitutional Order, 22 LEG. STUd. 340 (2002); Joseph Jaconelli, Do Constitutional Conventions Bind?, 64 CAMBRIDGE L.J. 149 (2005).
} 
would-be violation of the rule; and (ii) prevents the rule from being violated or violated with impunity. Enforcing a rule means ensuring it is honored, if not through obedience then at least by holding the violator to account. ${ }^{15}$

Judicial enforcement is simply enforcement by judges. We suspect that a common (and commonly overlooked) form of judicial enforcement is through informal criticism. Conventions are social rules, meaning that they emerge from a pattern of compliance with the rule coupled with acceptance in a social group that compliance is appropriate. ${ }^{16}$ Social rules are typically enforced through criticism of breaches of the rule. Conventions, too, can be enforced through criticism, and it can be judges who do the criticizing. For example, it is a convention in many jurisdictions that judges do not participate in party politics. If a judge gives a party political speech, and his or her colleagues reproach the judge, then they "enforce" the convention against the judge. Our focus in this Article is different. We are interested in the jurisprudence of conventions, and as such our interest is in a more formal judicial enforcement, by which we mean enforcement by judges through their judgments and findings.

The distinction between formal and informal judicial enforcement should not be confused with the distinction between legal and non-legal enforcement. Legal enforcement is enforcement which is an exercise of legal authority (for example, the imposition of a legal duty to pay a fine), or enforcement which is legally required or specially permitted by law (for example, the seizure of property for a failure to pay a fine). Although most formal enforcement is legal enforcement, there are exceptions, as we will explain. Our interest, then, is all manner of formal enforcement, whether legal or non-legal. Four types of formal judicial enforcement are especially important.

\footnotetext{
${ }^{15} \mathrm{We}$ can of course distinguish the coercive force of law from its directive force. See John Finnis, NATURAL LAW AND NATURAL Rights 313-14 (2d ed. 2011).

${ }^{16}$ For this account of social rules, see H.L.A. HART, ThE CONCEPT OF LAW 810, 55-57, 254-256 (3d ed. 2012). For the view that constitutional conventions are social rules, see JEREMY WALDRon, THE LAW (1990); Joseph Jaconelli, The Nature of Constitutional Conventions, 19 LEG. STUD. 24 (1999).
} 
1. Imposition of duties. Many rules are enforced through the imposition of further duties. Parking and speeding prohibitions are enforced through the imposition of an obligation to pay a fine. Contractual rules are sometimes enforced through duties of specific performance. Administrative rules are often enforced through duties to reconsider a decision (e.g., to deny a license) on a particular basis (e.g., with regard to a certain relevant factor, improperly ignored). And so on. In principle, constitutional conventions could be enforced in the same way. For example, if Queen Elizabeth II refused to appoint as Prime Minister the person who heads a government capable of commanding the confidence of the House of Commons, then a court might legally obligate her to do so. The convention would have been enforced via the imposition of a new legal rule.

2. Harsh treatment. This is probably the most familiar type of enforcement. By "harsh treatment" we mean to include any "evil" for the violation of a rule, such as criticism, corporal punishment, fines and denial of benefits. ${ }^{17}$ Harsh treatment is one of the law's main ways of enforcing its rules. The law's "plan A" is usually to impose duties, but if those duties go unfulfilled, the law resorts to "plan B," authorizing or requiring someone to treat the violator harshly. ${ }^{18}$ To illustrate, if someone speeds, she is ordered to pay a fine; but if she fails to pay the fine, the sheriff is authorized to garnish her wages, impound her car, or some similar form of treatment. Harsh treatment could, in theory, be the law's "plan B" for enforcing constitutional conventions. For example, judges could require or specifically permit constitutional actors to punish convention-breakers, or judges could impose punishments on convention-breakers invoking their own judicial authority. This is a remote possibility in practice, though, so we will not explore it further. Instead we

\footnotetext{
${ }^{17}$ See, e.g., John Austin The Province of JuRisprudence Determined 6 (1832). For a discussion of the importance of coercion and sanction in law, see FREDERICK SCHAUER, THE FORCE OF LAW (2015).

${ }_{18}$ Oona Hathaway \& Scott Shapiro, Outcasting: Enforcement in Domestic and International Law, 121 YALE L.J. 252, 271-73 (2011).
} 
turn to types of enforcement that are often not recognized as such.

3. Declaration. A rule may be enforced simply by drawing a person's attention, and if necessary the attention of the community, to her violation or would-be violation. Once a light is shone on her conduct in this way, the person may take it upon herself to either correct her behavior or to make amends. This is a mild response compared to other forms of enforcement. What nonetheless makes this a kind of enforcement is that the person has not been allowed to violate the rule without consequence.

If it seems strange to define declaration as a kind of enforcement, consider two examples from England and Wales. First, a standard administrative law remedy is a declaration that an administrative act is unlawful. ${ }^{19}$ The declaration does not invalidate the act, nor does it lead to damages or the like, nor even does it impose any ongoing obligation. Even so, declarations are often sought by complainants, and are considered "one of the most important remedies in review proceedings." 20 The reason is that the government almost invariably responds to a declaration by taking steps to avoid or correct for the illegality. Declarations enforce administrative law standards because the government is committed to acting lawfully, and because the government treats the court as an authority regarding its legal obligations. ${ }^{21}$ They are a form of

\footnotetext{
19 Senior Courts Act 1981, s. 31(2).

${ }^{20}$ Mark Elliott \& Jason VARUhas, Administrative LaW 455 (5th ed. 2017).

${ }^{21}$ Given that the government regards it as obligatory to comply with declarations of illegality, and that it regularly does so, it is plausible that there is a constitutional convention requiring compliance. The analogy would be with the emerging convention that Parliament will respond to declarations of incompatibility under the Human Rights Act 1998. See, e.g., AILEEN Kavanagh, Constitutional Review under the UK Human Rights ACT 1998 (2009), 289; Jeff King, Parliament's Role following Declarations of Incompatibility, in PARLIAMENT AND HUMAN RightS 171 (Murray Hunt et al. eds., 2015); Adrian Vermeule, The Atrophy of Constitutional Powers, 3 OXFORD J. LEG. STUD. 421, 442 (2012); see also British Coal Corp. $v$ The King [1935] AC 500, 511 (recognizing a constitutional convention that the King in
} 
legal enforcement because they are exercises of the legal authority to settle questions about whether the government has satisfied its legal obligations.

Conventions can likewise be enforced by judges through declarations. Suppose there is a general legal duty to comply with conventions. If a constitutional actor breaks a convention, then (provided any conditions regarding standing, justiciability, and the like were satisfied) a complainant could obtain a declaration of illegality. The declaration would be a form of legal enforcement, because it would be an exercise of legal authority.

Conventions can also be enforced through declarations as a form of non-legal enforcement. The scenario we have in mind parallels the legal case: the would-be convention-violator is committed to complying with her conventional obligations, and the person or body making the declaration is regarded as an authority on what the convention requires. The authority need not be a court. In the United Kingdom, for example, the Ministerial Code contains most of the important conventions applicable to ministers. ${ }^{22}$ The arbiter of what the Code requires is the Prime Minister, and her decisions are treated by ministers as conclusive. When the Prime Minister declares that some act would contravene the Code, other actors treat the matter as settled, and act accordingly. In this way, the Prime Minister enforces the Code. But of course, a court could also be treated as an authority on conventions. In such a case, a court's declaration that an act is not convention-compliant would be a form of nonlegal enforcement. Yet it would be a formal type of judicial enforcement.

4. Nullification. Declaring that someone's conduct would violate a rule may lead her not to violate it at all. If that occurs, it will be because she chose not to violate the rule, just as, for example,

Council, an executive body, will comply with the decisions of the Judicial Committee of the House of Lords, a judicial body).

22 CABinet Office, Ministerial CODE (December 2016), available at: https://www.gov.uk/government/uploads/system/uploads/attachment_da $\underline{\text { ta/file/579752/ministerial_code_december_2016.pdf }}$ (last visited Mar. 8, 2018). 
Parliament chooses to respect a court's declaration of incompatibility. Nullification-our second form of judicial acts not often seen as enforcement-is different. Here a court holds that a would-be violation of a rule is legally invalid or a legal nullity. The rule is enforced because its violation is prevented. This happens in Canada and India, where most legally entrenched constitutional rules are enforced by courts holding that acts contrary to those rules are legally null or invalid. Nullification is also the standard enforcement mechanism in administrative law, where courts routinely "quash" executive acts which run afoul of one of the grounds of review. ${ }^{23}$

Courts could, in principle, enforce conventions in just this way: they could hold acts contrary to conventions to be legal nullities (as they sometimes do, as we will explain in the next Part). They could invalidate acts of the executive which are at odds with a convention. More controversially, but no less consistently with how courts have acted in the cases we have described above, courts could treat legislation inconsistent with convention as invalid. For example, the legislature might create a statute that makes a convention otiose. It might create a legal regime for decision-making contrary to an existing conventional regime. Or it might pass a statute requiring political actors to perform an act that is inconsistent with what the convention requires. In each of these cases, judges might review the statute and invalidate it. They would treat conventions as though they were an entrenched part of the constitution.

\section{CONVENTIONS IN COURT}

We turn now to how British, Canadian, and Indian high courts have in fact engaged with conventions - or not. For each of the three modes identified above-recognition, employment and enforcement - we review whether and how each Commonwealth high court has exercised its authority when faced with a convention. Have British, Canadian, and Indian high courts all recognized, employed, and enforced constitutional conventions?

${ }^{23}$ For an overview of certiorari and quashing orders, see PAUL CRAIG, ADMINISTRATIVE LAW 803-10 (7th ed. 2012). 
We demonstrate that courts in all three jurisdictions engage with conventions, but in incrementally more ways: British courts employ conventions and recognize them for that purpose; Canadian courts go further and also declare, and thus judicially enforce, conventions; and Indian courts go furthest by legally enforcing conventions through nullification, specifically by voiding acts they determine are contrary to conventions.

\section{A. United Kingdom}

British judges are willing to employ conventions in legal reasoning, and to recognize conventions to that end. For example, the House of Lords has infamously deferred to the Home Secretary's judgment as to whether a person should be detained due to their "hostile associations." ${ }^{44}$ One reason for the court's deference was the Home Secretary's responsibility to Parliament-responsibility conferred on the Home Secretary as a result of a constitutional convention. Similarly, the Court of Appeal for England and Wales has set out what is now known as the "Carltona doctrine," holding that the act of a departmental official is considered the act of the minister of that department. ${ }^{25}$ The justification for this rule is, in part, the convention that the minister is responsible to Parliament for the official's acts. In these cases, conventions are supporting reasons for both particular legal decisions and the creation of general doctrines.

Usually, when a would-be convention is legally relevant, its existence is not in doubt. But when there is disagreement about whether a convention exists, British judges have been willing to reach a finding on the point. In Evans $v$. Information Commissioner, ${ }^{26}$ the issue was whether letters between Prince Charles government ministers, in which Prince Charles advocated for certain policy positions, had to be disclosed under the Freedom of Information Act 2000. That issue turned on

\footnotetext{
${ }^{24}$ Liversidge v Anderson, [1942] AC 206 (HL). Our claim is not that the case would be decided the same way today, but that recognition and employment of conventions by courts in the United Kingdom is nothing new.

${ }^{25}$ Carltona v Commissioner for Public Works, [1943] 2 All ER 560 (CA).

${ }^{26}$ Evans, supra note 11.
} 
whether disclosure would serve the "public interest." Disclosure would not serve the public interest, the court said, if it would undermine a constitutional convention. The "education convention" entitles Prince Charles to educate himself in the workings of government. Does that convention extend to advocating for policies? The court thought it needed to answer this question to resolve the overall issue. To do so, the court applied the Jennings test and concluded that the convention does not give Prince Charles a right to advocate for his personal views, ultimately ordering the letters disclosed. ${ }^{27}$

In Evans the court was willing to determine whether there is a convention for the purpose of answering a legal question. But would a court determine whether there is a convention to answer a political question? This question arose in 2016 when Britain voted to leave the European Union. To leave the EU, Britain would have to give notice of its intention to do so under Article 50 of the Treaty on the European Union. It was clear that notice would be given by the government. What was unclear was whether the government required Parliament's approval under statute to give notice. In Miller, the Supreme Court held that it did: statutory authority was necessary to start the Article 50 process. ${ }^{28}$ That conclusion settled the main issue in Miller, but it also made relevant a second issue, which is our concern here.

To explain the nature of the issue, we need to say something about devolution in Britain. In the 1990s, there was increasing pressure from Northern Ireland, Wales, and especially Scotland for greater powers. Britain responded in a series of a statutes which devolved power to these regions. However, given Britain's commitment to parliamentary sovereignty, the Parliament at Westminster would necessarily retain the power to legislate in any way, including to change the devolution arrangements themselves. And so there arose a convention, according to which Westminster would not legislate to change the devolution arrangements without the consent of the relevant

\footnotetext{
${ }^{27}$ For an older example of the employment of a convention in a common law context, see Attorney General v. Jonathan Cape Ltd, [1975] 3 All ER 484. ${ }_{28}$ Miller, supra note 8.
} 
government. ${ }^{29}$ This convention became known as the "Sewel Convention," after its first proposer.

The powers of the devolved institutions are currently legally limited in various ways. Specifically, the devolved legislatures and governments cannot act contrary to EU law applicable in Britain. In Miller counsel for the devolved governments argued that these restrictions would be effectively lifted were Britain to leave the EU. ${ }^{30}$ As a result, legislation authorizing the government to trigger Article 50 would expand the powers of the devolved governments, thereby changing the devolution arrangements. Hence the second issue in Miller: did the Sewel Convention require the consent of the devolved governments to a statute authorizing the government to trigger Article 50?

The Supreme Court refused to engage with this second issue. It conceded that courts "can recognise the operation of a political convention in the context of deciding a legal question." 31 However, it said, a court cannot "give legal rulings on [a convention's] operation or scope, because those matters are determined within the political world." ${ }_{22}$ The Court stressed that "judges are neither the parents nor the guardians of political conventions; they are merely observers." 33 Despite the importance of the Sewel Convention, "the policing of its scope and the manner of its operation does not lie within the constitutional remit of the judiciary, which is to protect the rule of law." ${ }^{34}$ From the Court's perspective, its proper sphere is law

\footnotetext{
${ }^{29}$ The convention also requires the Westminster Parliament to obtain the consent of the relevant legislature before legislating on a devolved matter. See Devolution Guidance Note 10, available at: http://www.gov.scot/Resource/Doc/37349/0066833.pdf (last visited Mar. 8, 2018). The Sewel Convention is now recognized in s 28(8) of the Scotland Act 1998, as amended.

so See, e.g., Written Case of the Lord Advocate (Scotland), available at: www.gov.scot/Resource/0051/00510602.pdf (last visited Mar. 8, 2018).

${ }^{31}$ Miller, supra note 8, at 146.

${ }^{32} \mathrm{Id}$.

${ }^{33} I d$.

${ }^{34} I d$. at 151 . The Court also considered parliamentary privilege a reason not to adjudicate on the scope of the convention: $I d$. at 145 .
} 
not politics, and its proper role is to uphold the legal rules of the constitution.

Given British judges' refusal to declare constitutional conventions to settle political controversies, it should come as no surprise that they are unwilling to legally enforce conventions. A 1963 case illustrates the point particularly well. ${ }^{35}$ Akintola was the Premier of Western Nigeria. A majority of members of the House of Assembly wrote to the Governor of the state, saying they no longer supported Akintola. The Governor dismissed Akintola, who responded by seeking a declaration that the Governor had acted unlawfully. Akintola argued that the members of the House of Assembly had not voted against him, and that dismissal based on a mere letter was contrary to convention. The case was eventually heard by the Privy Council, which rejected Akintola's argument. Although there "may be formidable arguments in favour of the Governor confining his ... [consideration] to the recorded voting in the House," it was not open to a court to create a "legal duty to observe" a requirement that he do so. ${ }^{36}$

In Akintola, the issue was enforcement of a convention through a declaration against a member of the executive. In Madzimbamuto v. Ladner-Burke $\&^{2}$ George, ${ }^{37}$ the question was whether a convention could be the basis for nullifying an Act of Parliament. The Imperial Parliament had legislated for Rhodesia, absent Rhodesia's consent, contrary to convention. The Privy Council rejected the suggestion that a convention could limit Parliament's powers. Certain acts of Parliament might breach a convention, the Court said, but that "does not mean that it is beyond the power of Parliament to do such things." 38 The Court then added: "If Parliament chose to do any of them the courts could not hold the Act of Parliament invalid." 39 Conventions, then, are not legally enforceable in the UK, against either the executive or Parliament.

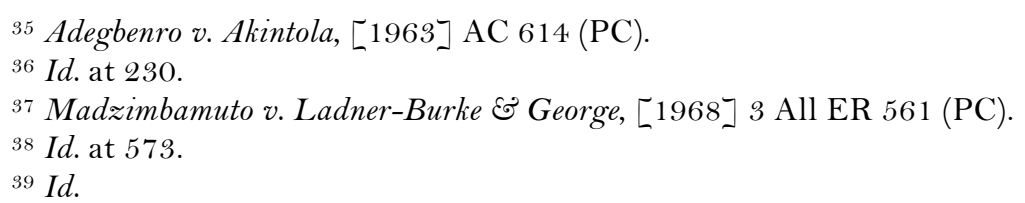




\section{B. Canada}

As in Britain, courts in Canada employ conventions as aids to resolving legal disputes, and acknowledge the existence of conventions for that purpose. ${ }^{40}$ Peter Hogg notes that when Canadian courts rely on conventions for this purpose, it is usually to interpret a statute or a codified part of the constitution. ${ }^{41}$ For example, the Supreme Court of Canada relied on the convention of political neutrality in the public service to evaluate the constitutionality of a statute that purported to regulate whether and how provincial civil servants and Crown employees engage in certain forms of federal political activity. ${ }^{42}$

Canadian courts have also engaged with conventions in ways that British courts have not. Specifically, the Supreme Court of Canada declared the existence of a convention in what was the most important constitutional controversy in modern Canadian political history. The Patriation Reference reached the Court in the midst of negotiations on whether and how to bring the Constitution home. ${ }^{43}$ The impetus behind patriation was to negotiate a procedure or set of procedures to finally grant Canada the power to formally amend its own constitution without the involvement of the Parliament of United Kingdom, which since 1867 had been the only body authorized, with few exceptions, ${ }^{44}$ to amend Canada's Constitution. ${ }^{45}$ When negotiations again broke down in 1981 after decades of failed efforts at reaching a federal-provincial agreement on

\footnotetext{
40 For an argument that Canadian courts have misused constitutional conventions in the resolution of constitutional questions, see Peter C. Oliver Constitutional Conventions in the Canadian Courts, UK Const. L. Ass'N BLOG, Nov. 4, 2011, at: https://ukconstitutionallaw.org/2011/11/04/peter-coliver-constitutional-conventions-in-the-canadian-courts (last visited Mar. 8, 2018).

${ }^{41}$ Peter W. Hogg, Constitutional Law of Canada 1-23 (5th ed. 2007).

${ }^{42}$ Ontario (Attorney General) v. OPSEU, [1987] 2 S.C.R. 2.

${ }^{43}$ See Patriation Reference, supra note 10.

${ }_{44}$ See Richard Albert, Amending Constitutional Amendment Rules, 13 INT'L J. CONST. L. 655, 673 (2015)

${ }^{45}$ Peter W. Hogg, Formal Amendment of the Constitution of Canada, 55 L. \& CONTEMP. PROB. 253, 253 (1992).
} 
patriation, ${ }^{46}$ the Government of Canada considered proceeding unilaterally without provincial consent.

The heart of the controversy in the Patriation Reference was this matter of provincial consent. As Canada was evolving from colony to dominion and then statehood, political actors adopted practices on how to amend the Constitution. The amendment process began in Canada with a joint resolution of the House of Commons and the Senate requesting from London an amendment to the Canadian Constitution, ${ }^{47}$ but all amendments had to be formalized as a matter of law by the Parliament of the United Kingdom. ${ }^{48}$ London would ultimately amend the Constitution as requested by the joint resolution. ${ }^{49}$

Over time, the Government of Canada developed a practice of first securing the consent of the provinces before seeking a joint resolution from Parliament for a major amendment affecting federal-provincial relations. ${ }^{50}$ By 1964, there had been sixteen formal amendments to the Canadian Constitution, and six of them involved federal-provincial relations. ${ }^{51}$ In each of these six instances, the federal government had first secured the approval of the provinces. ${ }^{52}$

The two fundamental questions for the Court in the Patriation Reference concerned the status of the federal government's practice of securing provincial consent before requesting from London major constitutional amendments affecting federal-provincial relations. First, was the Government of Canada bound by law to secure provincial consent before requesting the formal amendment from London? Second, was it

\footnotetext{
${ }^{46}$ See James Ross Hurley, Amending Canada's Constitution: History, Processes, Problems AND PRospects 25-63 (1996).

${ }_{47}$ William R. Lederman, Canadian Constitutional Amending Procedures: 18671982, 32 AM. J. CoMP. L. 339, 340 (1984).

${ }^{48}$ Peter W. Hogg, Constitutional Reform in Canada: A Comment on the Canadian Constitutional Crisis, 6 YALE STUd. WORLD. Pub. ORder 285, 287-88 (1980). ${ }^{49} I d$.

${ }^{50}$ Richard Albert, The Conventions of Constitutional Amendment in Canada, 53 OSGOODE HALL L.J. 399, 417 (2016).

${ }^{51}$ Guy Favreau, The Amendment of the Constitution of Canada 16 (1965).

${ }^{52} I d$. at $12-16$.
} 
required to do so by convention? On the first question, a 7-2 majority held that the Government of Canada could freely proceed unilaterally as a matter of law since there was no legal requirement requiring the federal government to secure provincial consent. ${ }^{53}$ On the second, a 6-3 majority held that the Government of Canada was bound by a constitutional convention requiring that the federal government proceed with patriation only with "a substantial degree of provincial consent." 54 The Court recognized the existence of this convention of substantial provincial consent using the Jennings test described above. ${ }^{55}$

Yet in the Patriation Reference, the Supreme Court stopped short of what it considered to be enforcing a convention. The Court believed that it could not enforce conventions because "they are generally in conflict with the legal rules which they postulate and the courts are bound to enforce the legal rules." ${ }^{6}$ The Court specified that "unlike common law rules, conventions are not judge-made rules. They are not based on judicial precedents but on precedents established by the institutions of government themselves. Nor are they in the nature of statutory commands which it is the function and duty of the courts to obey and enforce." ${ }^{57}$ And so, concluded the Court, "to enforce them would mean to administer some formal sanction when they are breached. But the legal system from which they are distinct does not contemplate formal sanctions for their breach." ${ }^{58}$ When confronted with a conflict between a convention and a legal rule in a constitutional or statutory text, therefore, the Supreme Court of Canada has preferred to give effect to the legal rule consistent with its recognition of the primacy of the text. ${ }^{59}$

The Court's declaration followed from a threatened violation of the convention. The declaration prevented the convention

\footnotetext{
${ }_{53}$ Patriation Reference, supra note 10, at 807.

${ }_{54} I d$. at 904-05.

55 See supra text accompanying notes 11-12.

${ }^{56}$ Patriation Reference, supra note 10, at 880-81.

${ }_{57} I d$. at 880.

${ }^{58} \mathrm{Id}$.

${ }_{59}$ British Columbia v. Imperial Tobacco Canada Ltd., [2005] 2 S.C.R. 473 at para. 67.
} 
from being violated with impunity, given the political pressure the declaration placed on political actors, who ultimately tailored their conduct to the convention. ${ }^{60}$ The analysis of enforcement we offered in Part II of this Article suggests that the Court's declaration in the Patriation Reference amounted to enforcement.

\section{India}

Like courts in the United Kingdom and Canada, the Supreme Court of India has employed constitutional conventions, and recognized them for that purpose. For example, the Court has employed conventions to understand the meaning of the text of the Constitution. ${ }^{61}$ But the Court has gone much further still.

In the famous Second Judges Case, the Supreme Court of India considered the process for transferring and appointing judges to the Supreme Court and High Court. The Constitution of India requires the executive to "consult" with the Chief Justice of India on judicial appointments. The issue was whether the Chief Justice would have "primacy" in these matters, such that her consent would be essential for appointments. To resolve this issue, the Supreme Court thought it should fill "gaps" in the constitution by "reading in" conventions. ${ }^{62}$ This language of "reading in" conventions may suggest that the Court is talking about employing conventions for the interpretation of legal provisions. ${ }^{63} \mathrm{We}$ explained earlier that conventions are often central to the interpretation of codified Constitutions. Understanding the implied meaning of the Constitution will often require judges to understand the conventions which the constitutional drafters took for granted. Among Commonwealth

\footnotetext{
${ }^{60}$ Adam M. Dodek, Courting Constitutional Danger: Constitutional Conventions and the Legacy of the Patriation Reference, 54 SUP. CT. L. REV. (2d) 117, 129-30 (2011).

${ }^{61}$ A.G. Noorani, Constitutional Questions and Citizens' Rights at s. I, Pt. 6 (2006).

62 Second Judges Case, supra note 11, at para. 456. To be clear, the conventions in question are not interpretive conventions such as the presumption against retrospectivity.

${ }^{63}$ See infra Subsection II.B.1.
} 
courts, employing conventions in this way is not controversial. But the Indian Supreme Court did considerably more in the Second Judges case.

The key opinion for our purposes is by Justice Kuldip Singh. His statements on conventions were explicitly endorsed by three of the nine judges, implicitly endorsed by one other judge, ${ }^{64}$ contradicted by no one, and treated favorably in a later Supreme Court decision. ${ }^{65} \mathrm{He}$ asked whether there was an "an established constitutional convention" that "the opinion of the Judiciary expressed through the Chief Justice of India is primal and binding" when appointing judges of the High Courts and Supreme Court. ${ }^{66}$ He concluded, using the Jennings test, that the convention that "the opinion and the recommendation of the Chief Justice of India in the matter of appointment of judges is binding on the executive, is firmly established" ${ }^{67}$ Once the existence of the convention was established, Justice Singh was clear about how the Court should engage with it.

While many have criticized the Supreme Court of Canada for declaring a convention in the Patriation Reference, Justice Singh in the Second Judges Case criticized the Supreme Court of Canada for not going far enough. ${ }^{68}$ The distinction between law and convention maintained by the majority in the Patriation Reference was "paradoxical," he said. Having concluded that infringing the established convention would be "unconstitutional," the only logical conclusion open to the Supreme Court of Canada was that the convention, "being part of the constitutional law of the land," had "binding effect" such that no "authority could have infringed the same." ${ }^{6}$ Justice Kuldip Singh favored the more radical approach of treating conventions as legally binding:

[O]nce it is established in the court of law that a particular convention exists and the constitutional functionaries are

${ }^{64} I d$. at para. 512. Note that Justice Verma described his judgment as an elaboration of his own.

${ }^{65}$ See National Judicial Appointments Commission Case, supra note 9.

${ }_{66}$ Second Judges Case, supra note 11, at para. 455.

${ }_{67} I d$. at para. 474.

${ }^{68} \mathrm{Id}$. at para. 447.

${ }^{69} \mathrm{Id}$. 
following the same as a binding precedent then there is no justification to deny such as convention the status of law... ${ }^{70}$

There is, he writes, "no distinction between the "constitutional law" and an established "constitutional convention." If someone comes to court seeking to enforce a convention, then the only question for the court is whether the convention exists. If it does, "then the convention becomes a part of the 'constitutional law' of the land and can be enforced in the like manner." ${ }^{11}$ We can imagine no clearer endorsement of the judicial enforceability of constitutional conventions.

In several cases, the Indian Supreme Court has legally enforced conventions through what we describe in Part II as nullification. In the Second Judges Case, the Court showed willingness to enforce a convention by invalidating an executive action. The Supreme Court went further in Madras Bar Association v. Union of India. ${ }^{72}$ The National Tax Tribunal Act, 2005 created a regime for tax matters. The Act's validity was challenged on several grounds, one of which was inconsistency with a convention relating to the essential characteristics of courts. ${ }^{73}$ The convention required that when a court (or tribunal) was constituted to substitute another, "the appointment and security of tenure of judges of that court would be the same, as of the court sought to be substituted." ${ }^{44}$ The Supreme Court accepted the argument, and invalidated the statute, thus treating convention as an independent basis for invalidation. ${ }^{75}$ Similarly, in Consumer Education Research Society v. Union of India, there was a challenge to the constitutional validity of an Act that would have altered who could stand for election to Parliament. One of the potential grounds for invalidity identified by the Supreme Court was a breach of a

${ }^{70} I d$. at para. 449 .

${ }^{71} I$ d. at para. 451.

72 Madras Bar Association v. Union of India, AIR 2015 SC 1571.

${ }^{73} I d$. at para. 91.

${ }^{74} I d$. at para. 71.

${ }^{75}$ This was not the only ground on which the Court would have invalidated the statute. See id. 
convention about legislative process during the Act's passage. The challenge was unsuccessful, but only because the practice was "merely a parliamentary procedure and not a constitutional convention." 76

Taken together, Madras Bar Association and Consumer Education Research Society show that conventions in India are not merely enforceable by declaration. As part of the constitution, conventions trump ordinary legislation, and are enforceable by nullification.

In its latest decision on conventions, the Indian Supreme Court has taken the strongest possible view thus far on the status on constitutional conventions: the Court has nullified constitutional amendments on the grounds that they would have subverted constitutional conventions. ${ }^{77}$

To understand the significance of this extraordinary development, we need to explain the events following the Second Judges Case. The case established that senior judges must "concur" the executive's appointments. This led to the collegium system, in which the most senior judges of the Supreme Court had "primacy" over the appointment process. Years later, Parliament tried to replace the collegium system with a National Judicial Appointments Commission, comprising the law minister and two "eminent persons" in addition to judges. Parliament tried to bring about this change by, first, passing the Constitution (Ninety-ninth Amendment) Act, 2014, intended to amend the Constitution, ${ }^{78}$ and second, by enacting the National Judicial Appointments Commission Act, 2014, which set out the details of the new scheme. ${ }^{79}$

The validity of both Acts were challenged in NJAC. ${ }^{80}$ According to the "basic structure doctrine" in India, the core commitments of the constitution are unamendable, even though the amendment procedure specified in the Constitution admits

\footnotetext{
${ }^{76}$ Consumer Education Research Society v. Union of India, 9 SCC 648 at para. 39 (2009).

77 NJAC, supra note 9.

${ }_{78}$ Constitution (Ninety-ninth Amendment) Act, 2014, No. 49, s. 3.

${ }^{79}$ National Judicial Appointments Commission Act, 2014, No. 48, s. 11.

80 NJAC, supra note 9.
} 
of no exceptions. ${ }^{81}$ Thus, Parliament's attempt to replace the collegium system would be invalid if the conventions relating to judicial independence — ving judges primacy in appointment decisions - formed part of the unamendable basic structure of the constitution. ${ }^{82}$ Through four complex separate opinions spanning almost 400 pages, the majority in $N J A C$ held that they did. The Court struck down the proposed Acts because they would subvert the conventions relating to judicial primacy in appointments; these conventions received detailed attention in the judgments. ${ }^{83}$ NJAC shows quite vividly that the Supreme Court is willing to enforce conventions through the nullification of not just ordinary executive and legislative action but even of procedurally compliant constitutional amendments.

\section{Progressive Engagement}

We have shown the dissimilarities in how courts in Canada, India and the UK engage with conventions. What emerges from our study thus far is an important correction to the mistaken belief that there is one "Commonwealth approach" to the treatment of constitutional conventions. We now know that courts in each jurisdiction engage with conventions differently. The table below maps the variation in judicial enforcement

${ }^{81}$ For a study of the basic structure doctrine, see SUDHIR KRISHNASWAMY, Democracy and CONSTITUTIONALISM In India: A STUdy OF THE Basic STRUCTURE DOCTRINE (2011).

${ }^{82}$ Or to be more precise, if the Court in the Second Judges Case had found that they formed part of the unamendable basic structure of the constitution.

${ }^{83}$ For criticism of the judgments in this case, see Rehan Abeyratne, Upholding Judicial Supremacy in India: The NJAC Judgment in Comparative Perspective, 49 Geo. Wash. InT'L L. REv. 569 (2017); Suhrith Parthasarathy, Assessing the NJAC Judgment, 3 J. NAT'L L. U. DELHI 25 (2015-16); Gautam Bhatia, The NJAC Judgment and its Discontents, INDIAN Const. L. \& PHIL., Oct. 16, 2015, at: https://indconlawphil.wordpress.com/2015/10/16/the-njac-judgmentand-its-discontents (last visited Mar. 8, 2018); Chintan Chandrachud, Debating the NJAC Judgment of the Supreme Court of India: Three Dimensions, U.K. CONST. L. BLOG, at: https://ukconstitutionallaw.org/2015/11/03/chintan-chandrachuddebating-the-njac-judgment-of-the-supreme-court-of-india-threedimensions (last visited Mar. 8, 2018). 
according to their degree of intrusiveness. The table moreover illustrates how far India has moved beyond Britain and Canada.

\begin{tabular}{c|c|c|c|c|}
\multicolumn{1}{c}{} & \multicolumn{1}{c}{ Recognition } & Employment & $\begin{array}{c}\text { Enforcement } \\
\text { (Non-legal) }\end{array}$ & $\begin{array}{c}\text { Enforcement } \\
\text { (Legal) }\end{array}$ \\
\hline \multirow{2}{*}{ Britain } & $\sqrt{ }$ & $\sqrt{ }$ & & \\
\cline { 2 - 5 } Canada & $\sqrt{ }$ & $\sqrt{ }$ & $\sqrt{ }$ & \\
\cline { 2 - 5 } India & $\sqrt{ }$ & $\sqrt{ }$ & $\sqrt{ }$ & $\sqrt{ }$ \\
\hline
\end{tabular}

Table I: Progressive Engagement with Conventions

In principle, other permutations are possible. A court could, for example, enforce conventions but refuse to employ conventions in other sorts of legal reasoning, or declare conventions but refuse to engage with them in any other way. But it is hard to see what would motivate these sorts of approaches, and we are not aware of any jurisdiction in which courts pursue any other approach. Together, the United Kingdom, Canada, and India illustrate the range of ways in which courts might realistically engage with conventions.

\section{CRYSTALLIZATION}

One of the "holy grails" ${ }^{84}$ of Commonwealth constitutional scholarship is a constitutional convention which has

\footnotetext{
${ }^{84}$ Barber, supra note 7, at 302. Barber claims that the Ministerial Code is a set of conventions which are in the process of crystallizing into law. Id. at 303309. Even if this is true, those conventions are not becoming laws of the British legal system. The significance of "crystallization" is somewhat different for scholars like Trevor Allan and Mark Elliott; the former has argued that conventions "express... conclusions of political principle, and so cannot, in the last analysis, be distinguished from the law." T.R.S. ALLAN, Law, Liberty, and Justice: The Legal Foundations of British CONSTITUTIONALISM 253 (1995).
} 
"crystallized" into law. There are examples of the codification of conventions into a master-text constitution, common in the independence and post-independence constitutions of the Commonwealth Caribbean, which have codified many of the executive power conventions inherited from the United Kingdom. ${ }^{85}$ And there are certainly examples of the content of a convention being enacted into law. In the United Kingdom, for example, it used to be a conventional requirement that treaties the government wanted to ratify be laid before Parliament; now it is a statutory requirement. ${ }^{86}$ But in both of these cases, the convention has not become a law; instead an act which was required by convention has come to be required by law. Crystallization occurs only if the source of the convention-i.e., the political custom which grounds the norm-is recognized as a source of law. Though this phenomenon has long been apparent in theory, "a concrete example of a convention crystallised into law and enforced as such remains ... elusive" 87 . It is interesting and significant, then, that crystallization in just this sense appears to have occurred in India.

On a positivist understanding of law, any legal system contains an ultimate rule of recognition. ${ }^{88}$ This rule of recognition is a "judicial customary rule," 89 that is, a social norm among judges and other law-applying officials, according to which they have a duty to apply norms meeting certain conditions. These conditions are sources of law. ${ }^{90}$ The norms that satisfy these conditions are legal norms. ${ }^{91}$ The conventions

\footnotetext{
${ }^{85}$ See Margaret De Merieux, The Codification of Constitutional Conventions in the Commonwealth Caribbean Constitutions, 31 INT'L \& COMP. L. Q. 263, 264-69 (1982).

${ }^{86}$ Constitutional Reform and Governance Act 2010, s 20.

87 Nicholas Aroney, Laws and Conventions, in Constitutional Conventions in Westminster Systems 44 (Brian Galligan \& Scott Brenton eds., 2015).

${ }^{88}$ See H.L.A. Hart, The CONCEPT OF LAw 94-95, 100-10 (3rd ed. 2012).

$89 \mathrm{Id}$. at 256.

90 Joseph RaZ, The AUTHORITy OF LAW 47-48 (1979).

${ }^{91}$ To be clear, this is a sufficient condition, not a necessary one. A norm can also be a law because it meets conditions in a norm which is itself recognized under the ultimate rule of recognition, as for example delegated legislation meets the conditions in an authorizing statute.
} 
at issue in the Indian cases issue from a specific type of political custom. To determine whether this custom is a source of law, and thus whether the norms it generates are legal norms, we can look at how the members of the relevant social group-i.e., lawapplying officials - act and think. If they recognize the norms issuing from the relevant type of political custom as laws, apply or enforce them in legal cases, and accept that they are under a duty to do so, then we have our answer: political custom is indeed a source of law, and norms like the one giving primacy to the Chief Justice in the judicial appointment process are indeed legal norms. Nothing more is required.

In the Second Judges case, Justice Singh clearly saw that judicial recognition and enforcement of a norm could lead to legal status:

We agree a convention while it is a convention is to be distinguished from the law. But this does not mean that what was formerly a convention cannot later become law. When customary rules are recognised and enforced by courts as law, there is no reason why a convention cannot be crystallised into a law and become enforceable. ${ }^{92}$

In this passage, Justice Singh charts a realistic path by which a convention may become law. Elsewhere in his judgment, though, Justice Singh suggests that the path has already been traveled, and that conventions are already laws. He says, for example, "that there is no distinction between the 'constitutional law' and an established 'constitutional convention." 93 This was a mistake, we think. For as we said the rule of recognition is a social norm. To change a social norm requires a consistent pattern of action and acceptance. Prior to the Second Judges case, there was no history in India of judicial enforcement of conventions or recognition of them as legal norms. Nor does the Second Judges case on its own suffice: one case does not make for a pattern. So Justice Singh was too hasty in his claim that in India conventions are laws.

However, the Second Judges case is now 25 years old, and matters have progressed since it was decided. Given subsequent

${ }_{92}$ Second Judges Case, supra note 11 , at para. 449.
${ }_{93}$ Id. at para. 451. 
developments, have we arrived at the stage that political custom is a source of law? Have some conventions at last crystallized into law? We tentatively answer "yes" to both questions. Our answer is yes for four reasons. First, as we described in Part III, there is a growing body of Supreme Court case law in which judges either enforce conventions or say they are willing to do so. Indian judges have gone even further than in the Second Judges Case, nullifying legislation and constitutional amendments inconsistent with conventions. Second, Indian judges give every impression of thinking that the enforcement of conventions is neither optional nor the exercise of discretion, but what they are duty-bound to do. Third, there is no plausible source of this duty other than the ultimate rule of recognition. The Constitution, for example, does not direct judges to enforce conventions. Fourth, there is no case in which judges have broken from this pattern and refused to treat conventions as legally binding.

Our answer is tentative because there have only been a handful of Supreme Court cases to consider the enforceability of conventions. Someone might doubt that four cases are enough to show a change in India's rule of recognition. In truth there is no precise measure of the extent or degree of judicial practice needed to establish a new source of law. A widespread, longstanding practice is obviously sufficient. A single case is obviously insufficient. In between will be some genuine borderline cases, about which reasonable people can disagree. To our minds, a series of four cases with no exceptions suggests that a new source of law has recently emerged in India. But we acknowledge that this is a borderline instance of crystallization, and that clarity will come only with the accumulation of future cases.

Someone might wonder whether we have contradicted our earlier claim that courts in India enforce conventions. Recall that we defined a convention as a non-legal rule of a constitution. If courts enforce conventions, then what they enforce are not laws, and crystallization cannot have occurred. If, on the other hand, crystallization has occurred, then the rules which are enforced are laws, not conventions. It would seem that we cannot maintain both that courts enforce conventions and that 
conventions have crystallized into laws. That is the worry. The solution is to distinguish between two time periods. Initially, what courts enforced were non-legal rules, that is, conventions. Eventually, that practice of enforcement, coupled with a change in judicial attitudes, brought about a shift in the rule of recognition, making what were once non-legal rules into legal rules. This does not mean that the rules enforced were never conventions; they were, and they were enforced as such, but over time their status has changed.

\section{CONCLUSIONS}

We began with the three largely unchallenged assumptions that there is a shared "Commonwealth approach" to constitutional conventions; that Commonwealth courts will recognize and employ conventions but never enforce them; and that conventions are always distinguishable from rules of law. In the course of challenging these assumptions, we offer in this Article four new insights on constitutional conventions.

First, we offer an account of the modes of judicial engagement with conventions which enriches our understanding of how courts employ and enforce conventions. This account draws attention to types of judicial employment that are rarely noticed, and offers a new and sophisticated understanding of the elusive idea of the "enforcement" of conventions.

Second, through a study of the dissimilarities in how courts in Canada, India and the UK engage with conventions, we correct the mistaken belief that there is one "Commonwealth approach" to the treatment of constitutional conventions. We show that there are significant differences in how courts in each of these Commonwealth jurisdictions engage with conventions.

Third, in a significant discovery that will force scholars of public law to rethink the conventional wisdom that Commonwealth courts never enforce conventions, we have shown in this Article that some Commonwealth courts in fact do enforce conventions: Canadian and Indian courts enforce conventions in a variety of ways.

Finally, our study has challenged the assumption that conventions are always distinguishable from rules of law. A 
study of the Indian Supreme Court's engagement with conventions over the last 25 years reveals, we have argued, that constitutional conventions have crystallized into law in this major Commonwealth jurisdiction.

These insights disrupt much of what is foundational in the study of constitutional conventions. They raise new questions and open up new avenues of research for constitutional scholars. The most pressing of these questions is the normative one that follows from the new descriptive reality we have uncovered: Commonwealth courts do enforce conventions, but should they? We think the answer is yes, and we explain why in a forthcoming article. ${ }^{94}$

94 Farrah Ahmed, Richard Albert \& Adam Perry, The Enforcement of Constitutional Conventions, _ INT'L J. CONST. L. (forthcoming 2019). 